\title{
Estimating Inequality with Tax Data: The Problem of Pass-Through Income
}

\section{Citation}

Patrick A. Sharma, Estimating Inequality with Tax Data: The Problem of Pass-Through Income (Harvard Law School, Sidney I. Roberts Student Writing Prize in the Field of Taxation, June 2015).

\section{Permanent link}

http://nrs.harvard.edu/urn-3:HUL.InstRepos:16386593

\section{Terms of Use}

This article was downloaded from Harvard University's DASH repository, and is made available under the terms and conditions applicable to Other Posted Material, as set forth at http:// nrs.harvard.edu/urn-3:HUL.InstRepos:dash.current.terms-of-use\#LAA

\section{Share Your Story}

The Harvard community has made this article openly available.

Please share how this access benefits you. Submit a story.

\section{Accessibility}




\title{
Estimating Inequality with Tax Data: The Problem of Pass-Through Income
}

\author{
Patrick Sharma*
}

April 30, 2015

In recent decades, a growing share of U.S. business income has been taxed on a pass-through basis. When taxed on a pass-through basis, business income is attributed to a firm's owners and taxed to them as individual income, rather than being subject to a separate entity-level tax. Among its many implications, the growth of pass-through taxation complicates our ability to estimate historical trends in income inequality. Prominent studies of income inequality use data from individual income tax returns to measure changes in the distribution of income over time yet fail to control for the increasing amounts of business income reflected in this data. Accordingly, to the extent that pass-through income flows to high-income individuals, such studies may overestimate the recent growth in income inequality.

This paper explores the effect of pass-through income taxation at the high-end of the income distribution. Using data from the World Top Incomes Database, it shows that the growth of passthrough income has been concentrated among the top 0.5 percent of taxpayers. The trend towards taxing business income on a pass-through basis may thus be responsible for some of the growth in income inequality that researchers have observed.

*J.D. Candidate, Harvard Law School. Email: psharma@jd16.law.harvard.edu. 


\section{Table of Contents}

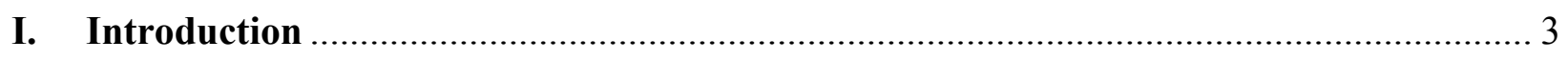

II. The Growth of Pass-Through Taxation .................................................................. 5

Figure 1: Share of Business Receipts by Type of Business, 1980-2007 ........................... 7

III. The Problem for Tax Data ................................................................................... 7

IV. Pass-Through Income at the High-End of the Income Distribution.......................... 10

Figure 2: Entrepreneurial Income as Share of Income for High-Income Groups............... 11

Figure 3: Top 10\% Share of Total U.S. Income, 1917-2012 ........................................ 13

Figure 4: Share and Composition of Income Received by Top 0.5\%, 1980-2011 ........... 14

Figure 5: Average Entrepreneurial Income (AEI) for Top Income Shares ...................... 15

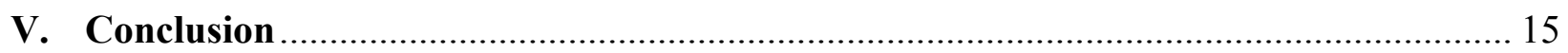




\section{Introduction}

The economists Thomas Piketty, Emmanuel Saez, and their collaborators in the World Top Incomes Database (WTID) have pioneered the use of tax data as a means of estimating historical changes in the distribution of income in the United States and elsewhere. ${ }^{1}$ Compared to other sources used to estimate income inequality, tax data has the advantage of providing a measurement of the distribution of income over a relatively long period of time, which facilitates historical analysis. However, the use of tax data to measure income trends presents a number of problems. Among these is the propensity of taxpayers to characterize their income in ways that reduce their tax burdens, so-called income shifting. For example, when tax rates increase, more income may take the form of nontaxable benefits. As a result, the "income" reflected in tax data may not remain steady over time, a problem the WTID researchers acknowledge. ${ }^{2}$

Pass-through income taxation represents one such distortion. In the United States, business income is generally taxed in one of two ways: it is subject to the corporate income tax, with distributions taxed to owners as dividend (or, in some cases, capital gains ${ }^{3}$ ) income, or it is passed through to the firm's owners and taxed to them as individual income. C-corporations are

\footnotetext{
${ }^{1}$ Facundo Alvaredo, Anthony B. Atkinson, Thomas Piketty \& Emmanuel Saez, The World Top Incomes Database (April 2015), http://topincomes.parisschoolofeconomics.eu/.

${ }^{2} I d$. at http://topincomes.g-mond.parisschoolofeconomics.eu/\#Introduction: ("The use of tax data is often regarded by economists with considerable disbelief. These doubts are well justified for at least two reasons. The first is that tax data are collected as part of an administrative process, which is not tailored to the scientists' needs, so that the definition of income, income unit, etc., are not necessarily those that we would have chosen. This causes particular difficulties for comparisons across countries, but also for time-series analysis where there have been substantial changes in the tax system, such as the moves to and from the joint taxation of couples. Secondly, it is obvious that those paying tax have a financial incentive to present their affairs in a way that reduces tax liabilities. There is tax avoidance and tax evasion. The rich, in particular, have a strong incentive to understate their taxable incomes.") See also Emmanuel Saez, Joel B. Slemrod, and Seth H. Giertz, The Elasticity of Taxable Income with Respect to Marginal Tax Rates: A Critical Review, NBER WORKING PAPER No. 15012 (May 2009).

${ }^{3}$ See 26 U.S.C. $\S 302$ (b) (certain distributions in redemption of stock treated as exchanges).
} 
subject to the former regime; sole proprietorships, partnerships, limited liability companies (LLCs), and S-corporations to the latter. For reasons explained below, in recent years fewer firms have paid the corporate income tax while a greater share of business income has been subject to pass-through treatment.

Among its many implications, the growth of pass-through income taxation complicates the data that the WTID researchers have used to estimate historical changes in the distribution of income in the United States. Because tax data includes pass-through income, and because passthrough income has increased significantly in recent years, such studies may overestimate the recent growth in income inequality, at least to the extent that pass-through income has flowed to high-income taxpayers.

This paper explores the consequences of pass-through income on the tax data used to estimate income trends in the United States. Although Piketty, Saez, and their collaborators' methods have been heavily scrutinized, I am unaware of any study that considers this issue in depth. ${ }^{4}$ By measuring some of the distributional effects of pass-through income growth, this paper seeks to obtain a more accurate estimate of recent income trends in the United States. I hypothesize that controlling for pass-through income reduces the amount of income inequality reflected in the tax data. However, this is only true to the extent pass-through income has flowed to high-income taxpayers. To the extent that pass-through income has flowed to taxpayers at lower ends of the distribution, tax data would underestimate the true level of income inequality. Thus, the real question is where pass-through income has been going. This paper focuses only on the distribution of pass-through income within the top 10 percent of the income distribution.

\footnotetext{
${ }^{4}$ See Scott Winship, How Much Has Inequality Risen-Low B.S. Edition, ScotT WinshIP WeB (November 11, 2009) (documenting some of the effects of pass-through income growth on the WTID data), http://www.scottwinship.com/1/post/2009/11/how-much-has-inequality-risen-lowbs-edition.html.
} 
Future research will consider the effect of pass-through income across the entire income distribution.

The paper proceeds as follows. Part II describes the growth of pass-through taxation in the United States. Part III explains why the growth of pass-through taxation poses a problem for the use of tax data in estimating income inequality trends. Part IV examines the distribution of pass-through income within the top 10 percent of the income distribution. Part V summarizes the results.

\section{The Growth of Pass-Through Taxation}

Over past three and a half decades, a steadily greater share of U.S. business income has been taxed on a pass-through basis. When taxed on a pass-through basis, a firm's income is attributed directly to its owners and taxed to them as individual income. Rather than being subject to a separate corporate income tax and taxed to owners only when earnings are distributed to them, business income is thus "passed through" directly to the firm's owners.

The growth of pass-through taxation has three main causes. The first is tax law. For most of the income tax's history, top marginal individual income tax rates were significantly higher than top marginal corporate income tax rates. However, since the 1980s individual and corporate rates have moved closer together. This development has reduced the incentive to retain business income in a corporation. ${ }^{5}$ At the same time, the creation of S corporations, limited liability partnerships (LLPs), and limited liability companies (LLCs) has meant that business owners no longer must incorporate as a $\mathrm{C}$ corporation to obtain the benefits of limited liability. ${ }^{6}$ Finally, the

\footnotetext{
${ }^{5}$ See Congressional Budget Office, TAXing Businesses through the Individual InCOME TAX (December 2012).

${ }^{6}$ See generally Robert W. Hillman, Limited Liability in Historical Perspective, 54 WASH. LEE L. REV. 615 (1997).
} 
“check-the-box" entity classification regulations adopted by the Treasury Department in 1996 eased the ability of business owners to obtain pass-through treatment for federal tax purposes. ${ }^{7}$

As a result of these developments, over the past three and a half decades pass-through income taxation has increased tremendously. From 1980 to 2007, the percentage of U.S. businesses organized as limited partnerships, S corporations, and LLC grew from 5 percent to 20 percent, while the percentage of U.S. businesses organized as C corporations declined from 17 percent to 6 percent. ${ }^{8}$ These trends have been reflected in the share of business income taxed on a pass-through basis. Although C corporations continue to account for the majority of U.S.

business receipts, their share of the total fell from 86 percent in 1980 to 62 percent in 2007, while business income taxed on a pass-through basis increased from 14 percent to 38 percent in that time. ${ }^{9}$

\footnotetext{
${ }_{8}^{7}$ See 26 C.F.R. $\$ 301.7701-1$, et seq.

${ }^{8}$ See Congressional Budget OfFice, TAXing Businesses through the Individual InCOME TAX (December 2012), 8 .

${ }^{9}$ Id.
} 
Figure 1: Share of Business Receipts by Type of Business, 1980-2007

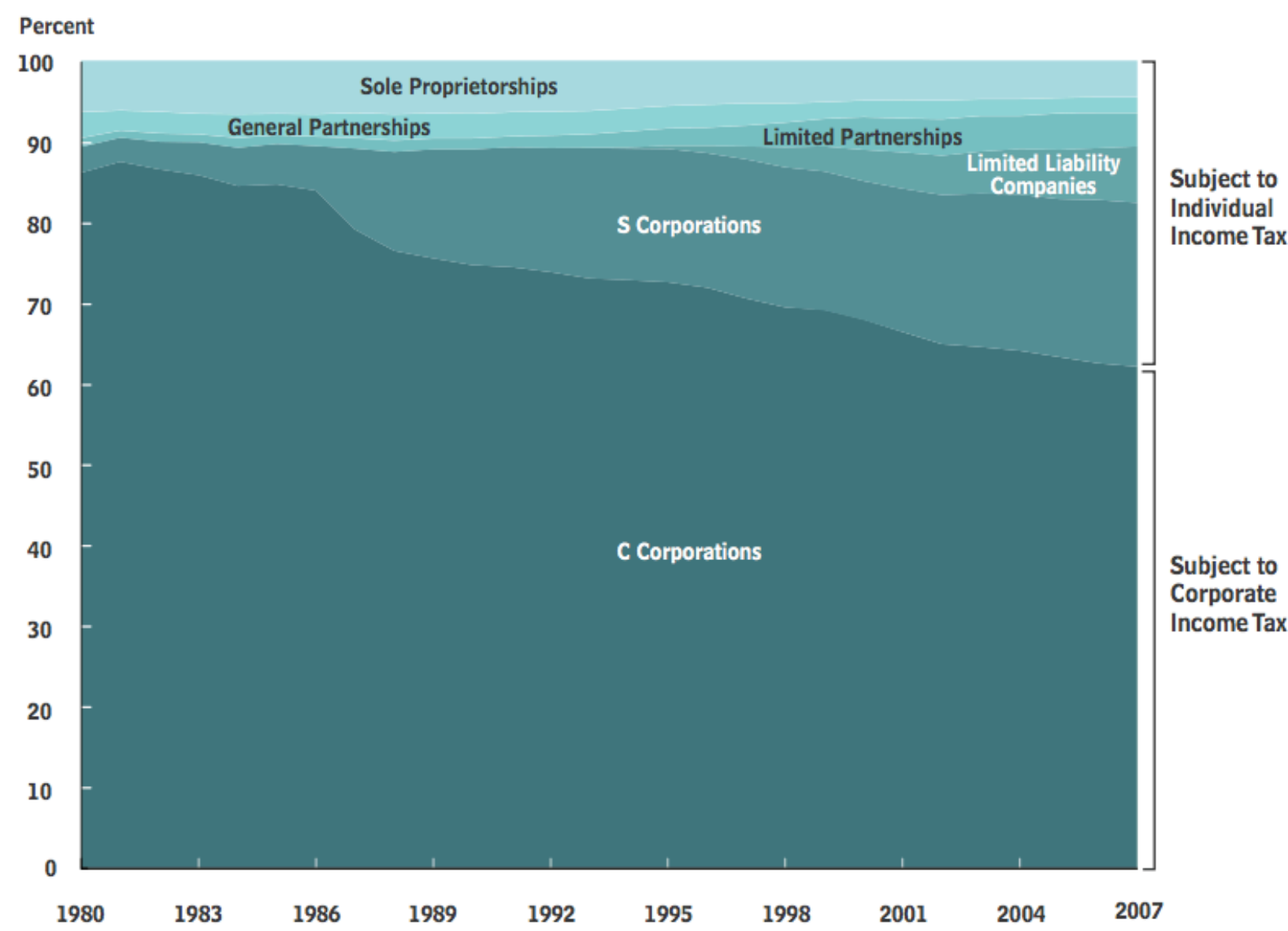

\section{The Problem for Tax Data}

The economists Thomas Piketty, Emmanuel Saez, and their collaborators in the WTID have pioneered the use of tax data as a means of estimating historical changes in the distribution of income in various countries. ${ }^{10}$ For the United States, the researchers have constructed a historical series based on data from the Statistics of Income (SOI) Division of the Internal Revenue Service (IRS). This data consists of large samples of individual income tax returns filed

${ }^{10}$ See Thomas Piketty and Emmanuel Saez, Income Inequality in the United States, 1913-1998, 118 THE QUARTERLY JOURNAL OF ECONOMICS 1 (2003). 
each year. ${ }^{11}$ In addition to the SOI data, the most widely used source for estimating income trends in the United States is the Census Bureau's Current Population Survey (CPS), which is based on annual survey of approximately 75,000 households. ${ }^{12}$ Tax data has a number of advantages over the CPS in measuring historical trends in the distribution of income. In the first place, tax data gives a picture of income over a much longer time period-from the onset of the federal individual income tax in 1913 to today — than is available from the CPS, which provides information on income distribution from the mid-1960s to the present. ${ }^{13}$ Moreover, tax data includes relatively detailed information on high-income taxpayers, whereas the CPS, for reasons of confidentiality, is "top-coded" so that all incomes over $\$ 1,099,999$ million/year are recorded in the data as $\$ 1,099,999 .{ }^{14}$ Given these advantages, analysts generally consider tax data "more accurate and more complete than survey data, such as the CPS" as a basis for estimating historical income trends at the high end of the income distribution. ${ }^{15}$

Tax data is not without its shortcomings, however. For one, not everyone files a tax return. Because the United States has historically exempted lower-income individuals from the federal income tax, high-income individuals may thus be overrepresented in the data. Moreover,

${ }^{11}$ See Internal ReVenue Service Statistics of Income, Individual Income Tax Returns, SOI TAX STATS, http://www.irs.gov/uac/SOI-Tax-Stats-Individual-Income-Tax-Returns.

${ }^{12}$ See United States Census Bureau, About the Current Population Survey, http://www.census.gov/cps/about/.

${ }^{13}$ For a comparison of the IRS and CPS data see Chad Stone, Danilo TRISI, ARLoc Sherman, AND BRANDOn DeBot, A Guide to Statistics on Historical Trends in Income Inequality, CENTER ON Budget AND POLICY PRIORITIES (February 20, 2015), http://www.cbpp.org/cms/?fa=view\&id=3629.

${ }^{14}$ Id. See also Richard V. Burkhauser, Shuaizhang Feng, Stephen P. Jenkins, and JefF LARRIMORE, Estimating Trends in US Income Inequality Using the Current Population Survey: The Importance of Controlling for Censoring, INSTITUTE FOR THE STUDY OF LABOR (September 2008).

${ }^{15}$ Chad Stone, Danilo Trisi, Arloc Sherman, and Brandon DeBot, A Guide to Statistics on Historical Trends in Income Inequality, CENTER ON BUDGET AND POLICY PRIORITIES, http://www.cbpp.org/cms/?fa=view\&id=3629. 
tax data does not include non-cash benefits and unreported cash income, the distributional consequences of which are more difficult to determine. Relatedly, tax data also suffers from the fact that taxpayers, particularly at the high-end of the distribution, may hide income or characterize income in ways that reduce their tax burdens. Additional complications arise from the fact that tax data measures income for a tax-filing unit, which is subject to manipulation, rather than at a uniform individual, household, or family-level.

The WTID researchers acknowledge these issues ${ }^{16}$ and have corrected for many of the shortcomings in their dataset. For instance, in constructing their historical time series for the United States, Piketty and Saez have used demographic information and other sources to estimate the income of non-filers in periods when only a small percentage of U.S. residents were subject to the federal income tax. ${ }^{17}$ Nevertheless, the WTID researchers have not analyzed the effect of pass-through taxation on their data. This is problematic. As noted above, a nontrivial and increasing amount of business income is reflected in individual income tax returns. Accordingly, as Harvard economist Greg Mankiw ${ }^{18}$ and the Cato Institute's Alan Reynolds and have noted, using tax data as a basis for estimating changes in the distribution of income may overstate the recent growth in income inequality, at least to the extent that pass-through income flows to high-income taxpayers. ${ }^{19}$

\footnotetext{
${ }^{16}$ See supra, note 2.

${ }^{17}$ See Anthony B. Atkinson, Thomas Piketty, and Emmanuel Saez, Top Incomes in the Long Run of History, 49 JOURNAL OF ECONOMIC LiTERATURE, 3, 20 (2011).

${ }^{18}$ See Greg Mankiw, The Growth of Pass-Through Entities, GREG MANKIW's BLOG (March 28, 2014), http://gregmankiw.blogspot.com/2014/03/the-amazing-growth-of-pass-through.html. ${ }^{19}$ See Alan Reynolds, Why Piketty's Wealth Data Are Worthless, Wall St. J., July 9, 2014 ("Moving capital income from one tax form to another did not mean the wealth of the top 1\% increased. It simply moved.”).
} 


\section{Pass-Through Income at the High-End of the Income Distribution}

This section considers the effect of pass-through income growth in the top 10 percent of the income distribution. It focuses on the top 10 percent both because the majority of passthrough income flows to this group and because of the relative richness of the data. ${ }^{20}$ The WTID $^{2}$ provides income composition data on five different groups within the top 10 percent: $10-5$ percent, 5-1 percent, 1-0.5 percent, 0.5-.1 percent, and 0.1-001 percent. The WTID divides income into five categories: (1) wages, salaries, and pensions; (2) entrepreneurial income; (3) dividends; (4) interest income; and (5) rents. ${ }^{21}$ Entrepreneurial income (EI) consists of "business, farm, partnerships, and S corporation income" and is thus synonymous with pass-through income. $^{22}$

The chart below compares the shares of EI as a component of total income for each highincome group. Two trends jump out. The first is the long-run pattern of EI. In the late 1930s, the top 5 percent of taxpayers began to derive an increasingly large percentage of their income from entrepreneurial activities. This trend peaked in the mid-1940s, after which followed a period in which EI declined as a percentage of income across all high-income groups. Interestingly, this was also the period of historically low-income inequality across the entire income distribution. By the early 1980s, high-income taxpayers were deriving on average less than 10 percent of their income from entrepreneurial activities. Since then, however, EI has increased as a percentage of income for all groups. Much of this might be due to changes in the structure of the economy, but

\footnotetext{
${ }^{20}$ The WTID provides data on the composition of income among the top 10 percent but not for the bottom 90 percent.

${ }^{21}$ The WTID also provides data on capital gains income, but this is not included in the composition of income statistics.

22 Thomas Piketty and Emmanuel Saez, Income Inequality in the United States, 1913-2002, (November 2004), 35, http://eml.berkeley.edu/ saez/piketty-saezOUP04US.pdf.
} 
it might also be partially explained by the shift towards pass-through treatment of business income.

Figure 2: Entrepreneurial Income as Share of Income for High-Income Groups, 1918-2011

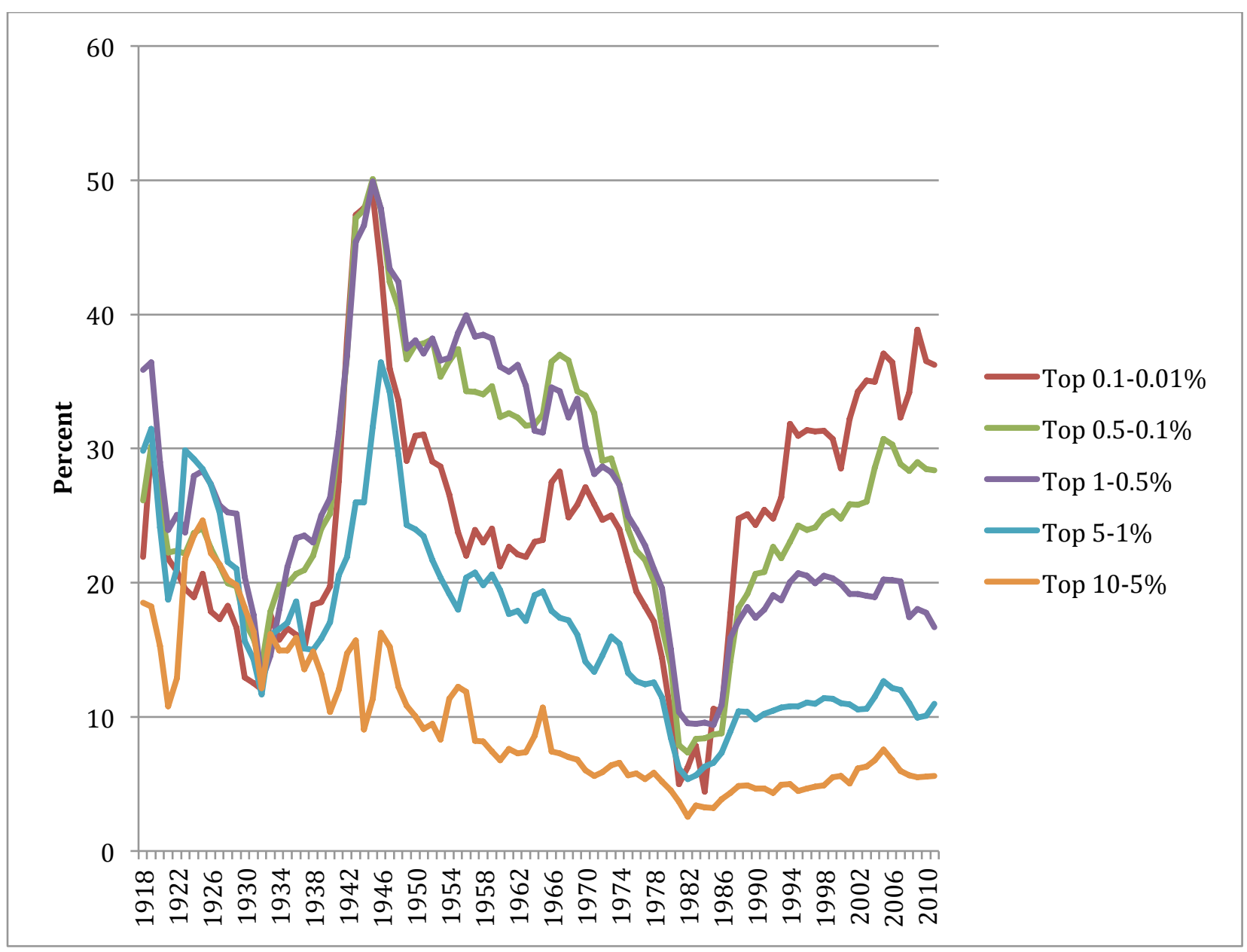

The second thing to notice is that, while EI constitutes a significant component of income for all high-income groups, this is particularly true for those at the upper end of the distribution. Since the early 1980s, the percentage of income attributable to entrepreneurial activities has been much greater for the top 1 percent of taxpayers than it has for the top 10-1 percent, with the top 0.5 percent of taxpayers deriving an especially high percentage of their income from EI. As with long-run trends, the recent growth of EI among very high-end taxpayers might be the result of 
economic changes and/or income shifting. It is impossible to know exactly how much each factor contributes to the trend.

Examining general income trends does, however, allow us to make some interesting inferences regarding the top 0.5 percent. Among the noticeable aspects in the chart below, which was also produced using the WTID, is the spike in the income shares of the top .05 percent from 1986 to 1988. These spikes may be attributable to the Tax Reform Act of 1986, which brought top marginal individual tax rates below top marginal corporate tax rates for the first time. As described above, this shift in corporate and individual tax rates was one of the major causes of pass-through income growth. Interestingly, no group outside the top 0.5 percent experienced a similar spike during this time. We may thus hypothesize that the top 0.5 percent took advantage of the 1986 Act to shift business income from corporate to pass-through treatment. 
Figure 3: Top 10\% Share of Total U.S. Income, 1917-2012

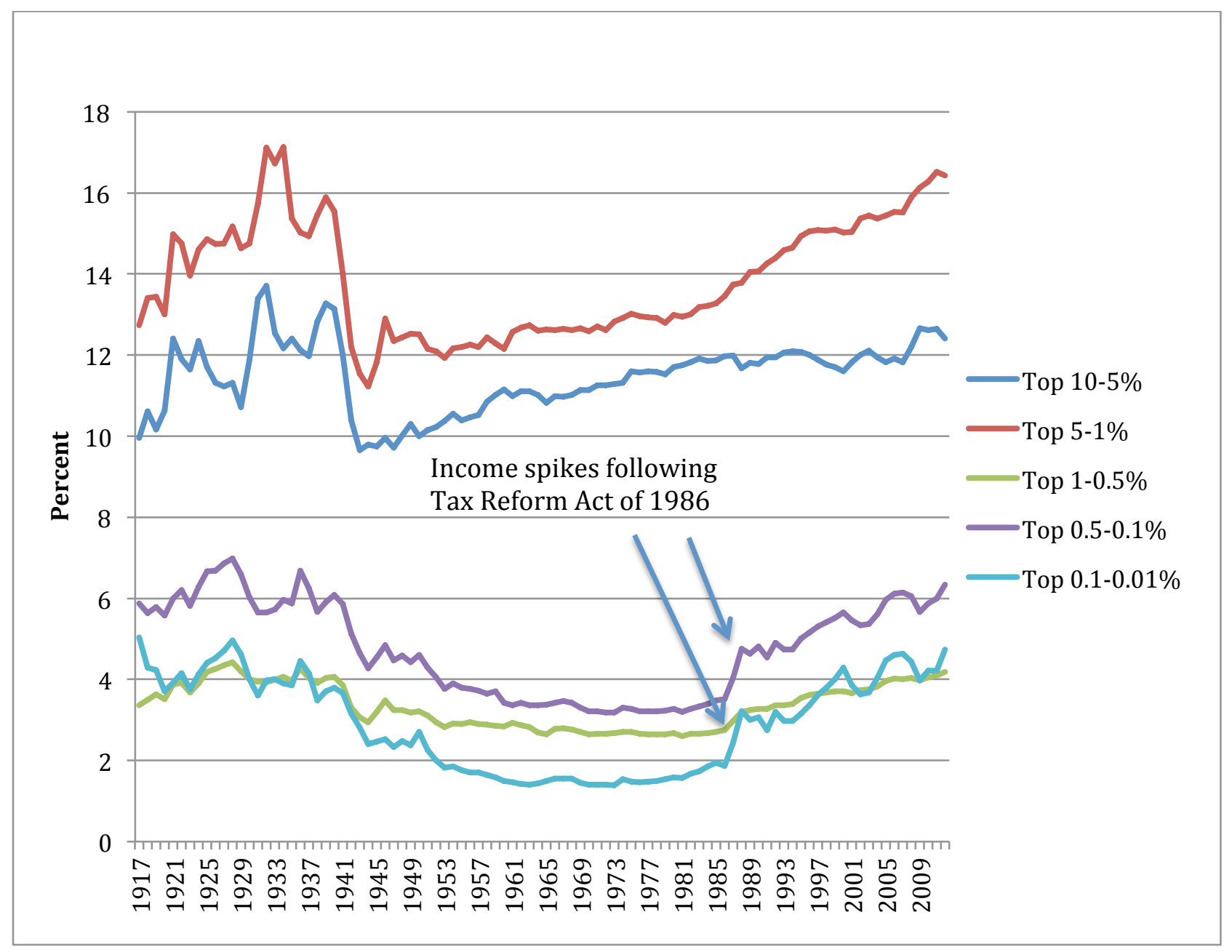

The data also shows that this was not a one-time event. Rather, as the chart below demonstrates, much of the growth of the top 0.5 percent's total income share is attributable to EI. 
Figure 4: Share and Composition of Income Received by Top 0.5\%, 1980-2011

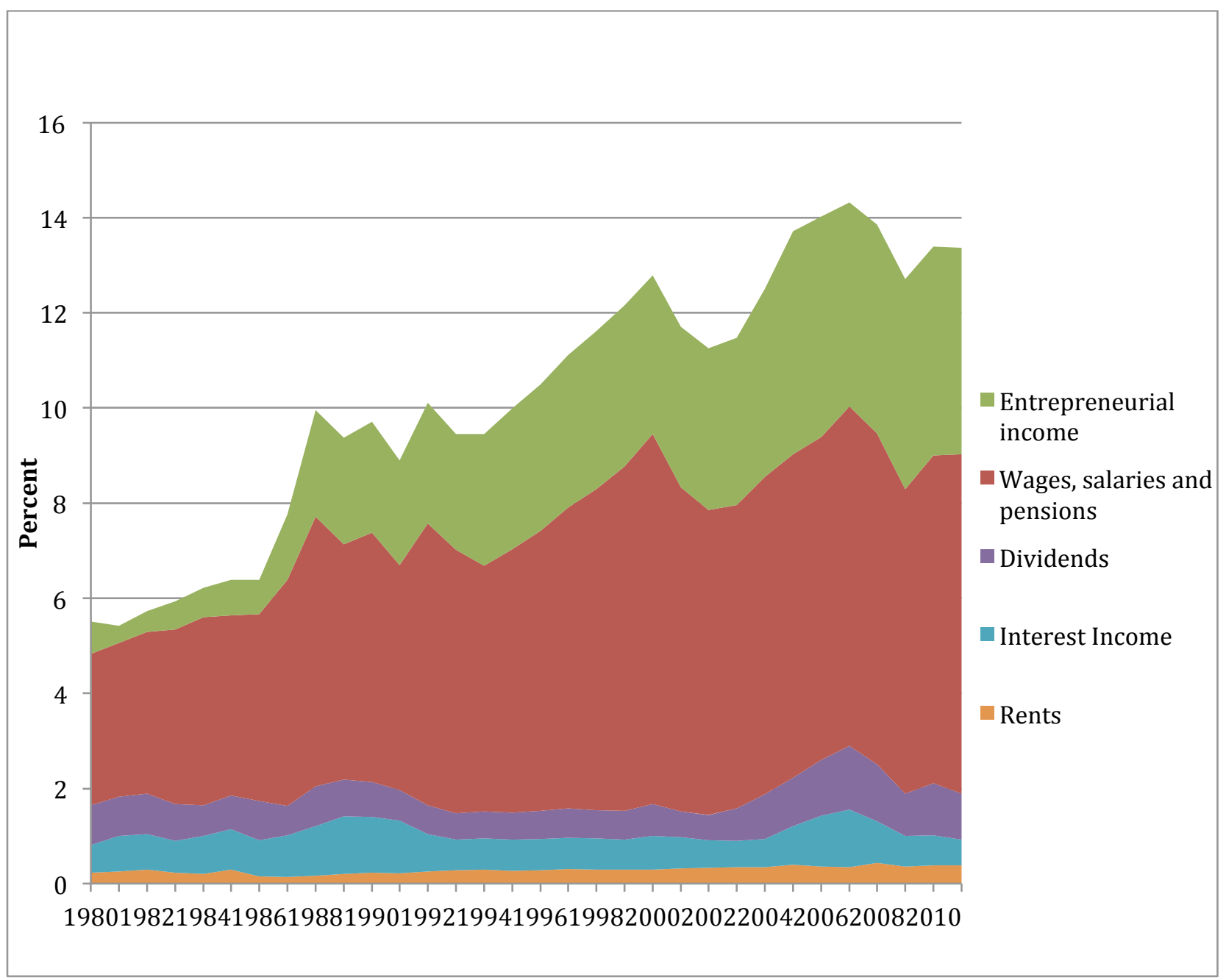

The WTID also allow us to estimate the amount of entrepreneurial income flowing to different high-income groups. The WTID does not present this data directly. Instead, we derive this measure from available data, including the average annual income (AI) of each group in the top 10 percent of the income distribution. For each year, we multiply the percentage share of a given group's EI by its AI. This yields a measure of average entrepreneurial income (AEI), which we can use to establish the average amount of pass-through income flowing to a taxpayer in a particular group. Of course, AEI, because it does not account for the wide disparities in 
overall income between high-income groups, does not tell us much about the degree to which pass-through income has been distributed among the top 10 percent. However, AEI does provide a general sense of the quantities in question.

Figure 5: Average Entrepreneurial Income (AEI) for Top Income Shares, 1918-2011

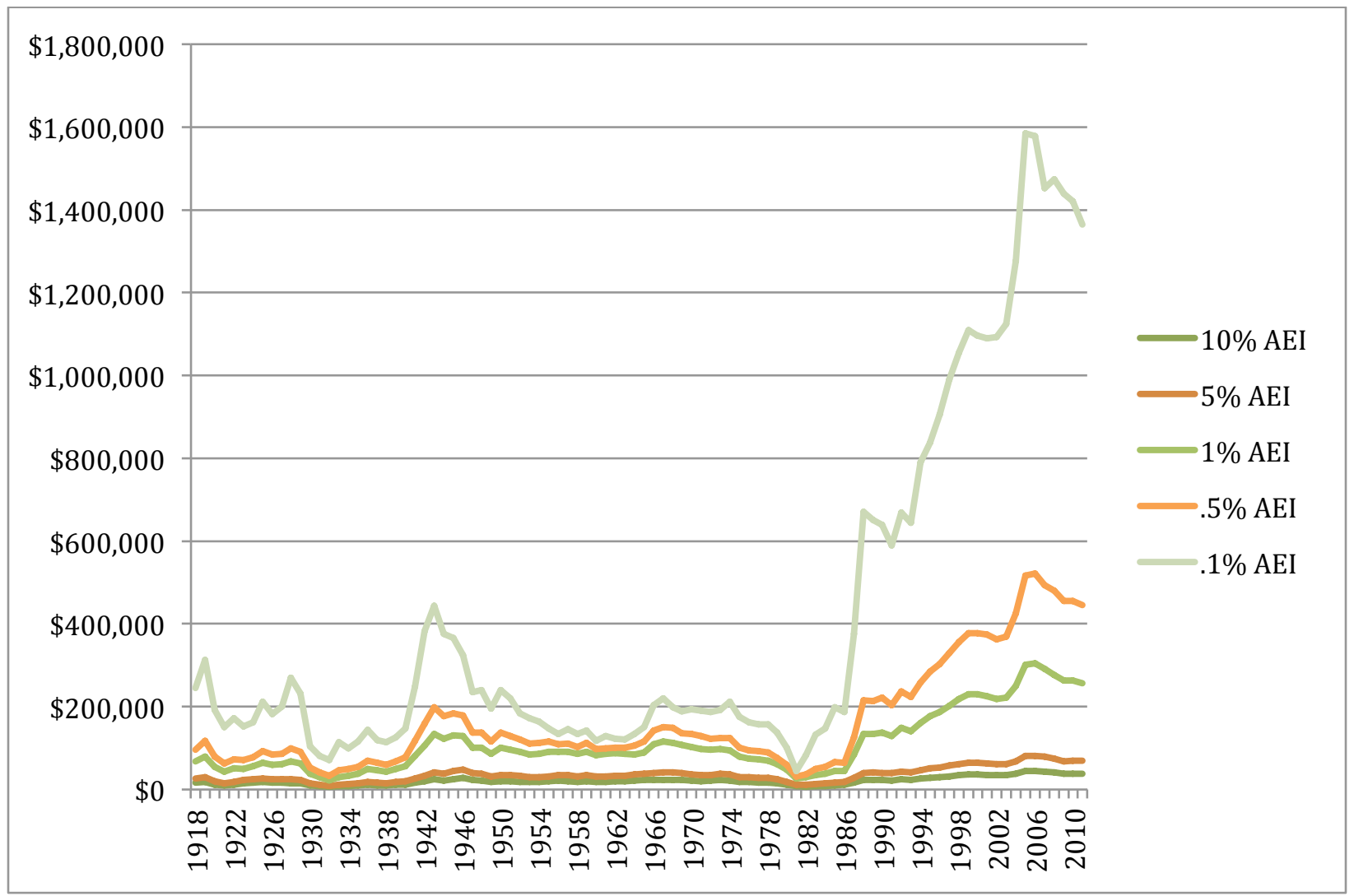

\section{Conclusion}

\section{A. Controlling for pass-through income concentration at the top of the distribution}

This paper has identified a potential shortcoming of the data used to draw conclusions about trends in income inequality in the United States. Where business income was once taxed almost entirely at the corporate level, it increasingly manifests as individual income. While some of this development may be due to changes in the structure of the economy, it also represents a 
form of tax shifting. As such, estimates of the recent growth of income inequality may be inflated. At the very least, the data presented above makes it clear that pass-through income has been a critical component of the growing share of income captured by the top 0.5 percent of taxpayers.

So far, researchers have failed to analyze or control for this effect. Further analysis may shed light on how much of the EI growth is attributable to tax shifting and how much is due to structural economic changes. To the degree that researchers find that tax shifting is behind this trend, they may wish to control for this effect. One way to do so would be to adjust the top 0.5 income shares downward based on comparisons with other countries or with other data sources, although either approach is subject to its own shortcomings. ${ }^{23}$ Simply subtracting EI from the income share, holding EI steady over time, or controlling so as to mirror growth in other income groups is also problematic because doing so would fail to distinguish how much of EI growth is due to tax shifting and how much to structural changes in the economy. Another way to think about EI growth would be to examine trends in dividend income over time: to the extent that business income is being shifted to individuals, dividend payments may be expected to decline. Although each of these methods is imperfect, future research should shed some light on the extent to which income inequality at the top end has been inflated by a shift to taxing business income on a pass-through basis.

\footnotetext{
${ }^{23}$ For instance, while researchers have attempted to reconcile tax data with CPS data, they have not been able to do so for the top 1 percent because of the limitations of CPS data. See Richard V. Burkhauser, Shuaizhang Feng, Stephen P. Jenkins, and Jeff Larimore, Recent Trends in Top Income Shares in the USA: Reconciling Estimates from March CPS and IRS Tax Return Data, NBER WORKING PAPER NO. 15320 (September 2009).
} 


\section{B. Pass-through income across the entire distribution}

Another area of future research concerns the distribution of pass-through income across the entire income distribution. This paper has only considered the distributional effects of passthrough income among high-income taxpayers. It has not addressed the question of how passthrough income is distributed across the entire income distribution. It is generally assumed that high-income taxpayers receive the majority of pass-through income. However, as with the highend of the distribution, knowing precisely how much pass-through income goes to which income groups is important if we want to determine the effect of pass-through income growth on the entire income distribution.

To answer this question, researchers will need to look beyond the WTID. Befitting its name, the WTID includes much more information on incomes at the top end of the distribution than it does for incomes below the top. Specifically, while the WTID provides historical data on the annual composition of income for taxpayers in the top 10 percent of the income distribution, it does not do so for the bottom 90 percent of taxpayers. As a result, we cannot directly measure the distribution of pass-through income across the entire distribution using only WTID data.

One way to solve this problem would be to reconcile the WTID with other data. Yearly totals of pass-through income are available from the SOI's Integrated Business Dataset (IBD). The IBD includes information on the number of returns, total receipts, business receipts, and net income of S corporations, partnerships, and nonfarm sole proprietorships from 1980 to 2008 and for LLCs from 1993 to $2008 .{ }^{24}$ Theoretically, we can use WTID and SOI data to estimate the share of pass-through income flowing to taxpayers below the top $10 \%$. This will give us a sense

\footnotetext{
${ }^{24}$ See Internal ReVenue Service Statistics of Income, Table 1: Selected financial data on businesses, SOI TAX STATS-INTEGRATED BUSINESS DATA, http://www.irs.gov/file_source/pub/irs-soi/80ot1all.xls.
} 
of the effect of pass-through taxation across the entire income distribution. To obtain a measure of the total amount of pass-through income flowing to the bottom $90 \%$, we would subtract the total amount of entrepreneurial income flowing to the top $10 \%$, which we can derive from the WTID, from the total amount of pass-through income for each year, which is represented in the net income figure. ${ }^{25}$ In practice, reconciling these two data sources has proven difficult, in part because the IBD figures do not seem to capture all of the EI represented in the WTID data. In a future paper, I plan to look more closely at this issue in the hopes of determining the distribution of pass-through income across the entire income distribution.

\section{Business income as personal income}

This paper has proceeded from the assumption that it is important to account for the effects of pass-through income on total income figures. However, this assumption is not selfevident. In fact, there is some justification for treating pass-through income as a form of individual income. For instance, pass-through income can often be viewed as a form of labor income, as in the case of a sole proprietorship or partnership. Still, in many cases taxpayers may choose to receive pass-through income to avoid paying the corporate income tax. In such situations, pass-through income may capture income that might be more attributable to tax shifting than underlying economic changes.

Given these competing conceptions, the WTID researchers' failure to control for the growth of pass-through income does not necessarily undermine their basic conclusion that income inequality is increasing. Rather, it points to the difficulty of defining income consistently. Income is a concept that is open to multiple definitions and which has been measured differently

\footnotetext{
${ }^{25}$ Net income should be used because Schedule E of Form 1040 reports out passive income and loss combined with non-passive income and loss for partnerships and S corporations.
} 
over time. As such, analyses such as those provided by the WTID are best read as estimates of general trends rather than definitive statements of historical fact. 